\title{
Religion and the Order of Nature
}

\author{
by Seyyed Hossein Nasr. New York and Oxford: Oxford University \\ Press, 1996, 310pp.
}

Even by his own exceptional standards, this new book by Seyyed Hossein Nasr is a remarkable work destined to be a classic in the field of religious studies of nature. Professor Nasr brings together a breath-taking depth of knowledge in a single volume - he covers the fields of metaphysics and comparative religion, traditional cosmology and modern philosophies of nature, as well as the history of science and the rise of secularism and humanism. The book is especially relevant to this issue, which is dedicated to economics as applied ethics, for Professor Nasr argues that the environmental crisis is an external reflection of modern man's spiritual crisis. While others naively believe that a more clever use of technology will avert the impending environmental calamity, Professor Nasr demonstrates that what really needs to be addressed and remedied is modern man's misguided search for the infinite in a finite world. Rather than satisfying his yearning through religion and spirituality which leads to the Infinite, modern man pursues material objects in an external world divorced from its spiritual significance as a sign of God. The result is internal dissatisfaction, giving rise to insatiable appetites and the environmental crisis. While Professor Nasr documents this work with a wealth of data and detail, the reader is never allowed to lose sight of the essential. As one of his admiring readers noted, "The book has the form of academic research but the substance of metaphysical insight; the penetrating acuity of the logician is combined with the spiritual sensibility of the contemplative."

For Professor Nasr, the contemplative appreciation of the world of nature is essential to avert an environmental catastrophe and does not detract from objective science, rather it is a fulfillment of it. Indeed, the intelligence is objective to the extent that it accurately registers, not only that which is, but also all that $i$. In this sense, true objectivity requires one to know things as they are in divinis, corresponding to the hadith of the Prophet in which he asks God to show us things as they really are. Objectivity does not consist in denying the qualitative dimension of nature as symbols leading man to God, and taking its quantitative dimension to be the only reality. Professor Nasr relates this incomprehension of the spiritual significance of nature to the environmental crisis and denial of man's spiritual needs. He points out that this quantitative approach is to take a part to be the whole, and is evidence of partiality rather than objectivity. For those who recognize that the current environmental crisis cannot be understood, much less solved, without a wider spiritual approach, Professor Nasr's book will be both enlightening and a source of consolation.

Based on his 1994 Cadbury Lectures delivered at the University of Birmingham, England, this book complements an earlier classic, Knowledge and the Sacred. Whereas his earlier book focused on the desacralization of knowledge in the modern West, his new book is concerned with the desacralization of nature. At the root of both errors is an attitude which creates an internal world of reason cut off from both the intellect and Revelation, and an external world cut off from its spiritual significance as a sign from God. 
The book consists of eight chapters, each supported with copious references and notes which both substantiate the arguments made and introduce the reader to spiritual works that transcend the quantitative perspective. As Kazemi, a scholar of comparative religion and traditional teachings, notes, "Professor Nasr meets the most exacting standards of scholarship and satisfies the thirst of the seeker: at a time when ever-increasing numbers are being driven by the ravages of the environmental crisis to reconsider such conventionally hallowed ideas as 'progress' and 'development', this book will be of the utmost significance in reorienting them towards the realm of traditional intellectuality that can alone provide a meaningful critique of modern society." The following overview of each chapter also draws from Kazemi's valuable commentary on Professor Nasr's book.

The opening chapter, "Religion and Religions," addresses the question of how to study religions, a necessary prelude since the purpose of the book is to "understand the relation of religion to the order of nature on a global scale rather than from the perspective of a single tradition." (p. 10) First, Professor Nasr examines the way in which religions differ with respect to their outer forms, while being united in respect to their source and substance. Many of his readers will be familiar with this perennialist thesis that each religion contains the Truth and a means for attaining the Truth, while emphasizing a particular aspect of Truth in conformity with the spiritual and psychological needs of the humanity for whom it is destined. Professor Nasr draws an image from the world of nature to explain this. The Ultimate Reality that is the origin of the sacred is likened to

a mighty spring gushing forth atop a mountain, It gives rise to cascades of water that descend with ever-greater dispersion from each side, each cascade symbolizing all the grades of reality and the levels of cosmic, and, by transposition, metacosmic reality of a particular religious universe. Yet all the cascades issue from a single Spring and the substance of all is ultimately nothing but the water which flows from the Spring at the mountaintop, the Reality which is the alpha of all sacred worlds and also the omega to which all that is within their embrace returns. (p. 12)

The second chapter on "The Order of Nature" assesses the order of nature from the point of view of these different religious traditions which emphasize different aspects of the Truth. Professor Nasr exhibits an astonishing depth of knowledge on the religions of the world, selecting perspectives that indicate the essential elements of each. He provides a breath-taking survey of the different religious landscapes, covering the Primal religions, Shamanism and the American Indian traditions, Taoism and Confucianism, Hinduism, Buddhism, Zoroastrianism, the Greek religions, and finally Abrahamic monotheisms. He calls the convergences which bring these different traditions together the "universal heritage of the religious view of the order of nature," which is an aspect of the "perennial cosmology." Professor Nasr beautifully integrates these convergent principles, and explains them in the following way:

The first is that the order of nature is related to an order "beyond" itself, to what we might call "spiritual principles." Traditional religions agree that the reality of nature has a significance beyond its appearance, that there is a "sacred" quality within nature. . . Second, the order of nature has a purpose, a meaning, and this meaning has spiritual and moral 
significance for human beings. Third, the human and natural orders are intertwined in a bi-unity in such a way that their destinies are interrelated not only here and now but even in that ultimate state that is eschatological. Fourth, the laws of man and the laws of nature are not totally distinct but are again closely interrelated and in some traditions the same, as in such key concepts as Tao, rta, al-Shari'ah and sunnah (p. 65)

Given this spiritual norm, Professor Nasr discusses "Philosophy and the Misdeeds of Philosophy" in the following chapter. He charts the development of Western philosophy, locating the rebellion of the post-medieval West against the traditional Christian view of man and nature. He discusses how the positive elements of Greek schools of philosophy could easily be accomodated within the Abrahamic religions, but points to the seeds of rationalism in its later stages which came to fruition during the Enlightenment and Renaissance. The Thomistic view of nature against which philosophy in this period rebelled was a profoundly religious one, although it did not stress symbolism. Many writers now suggest that one should not blame the Renaissance for the later abuses inflicted on nature in the name of science because nature was still viewed as divine (though purely by sentiment) at that time. Professor Nasr responds decisively by demonstrating the futility of attempting to make nature holy outside of the great religions. He writes that this sentimental Renaissance approach to nature did not

lead to a rediscovery of the sacramental character of nature because the conception of nature as "divine" took place for the most part outside the sacred world of Christianity and was independent of a revealed universe of meaning. . . cut off from the protection of a living tradition, and this gave way very rapidly during the latter years of the Renaissance to a mechanistic view of the world dominated by mathematics. (p. 101)

Professor Nasr then presents the decline into a mechanistic view of the world, both natural and social. From the Copernican revolution to Cartesian dualism, and from Comtean positivism to Darwinian evolutionism, he surveys the decline of the West into increasingly gross forms of materialism. However, eventually he strikes a positive note with a summary of the perennialist school's view of nature, drawing primarily from writings on the cosmic and natural order by Frithjof Schuon.

The next two chapters on the "Scientific Revolution" and the "Tragic Consequences of Humanism in the West" continue the incisive analysis of the post-medieval worldview deviation. Regarding the defining characteristic of the new science after the Renaissance, Professor Nasr writes that it marked

the first occasion in human history when a human collectivity completely replaced the religious understanding of the order of nature for one that was not only nonreligious but that also challenged some of the most basic tenets of the religious perspective. (p. 130)

While all the previous sciences of nature were intrinsically related to the metaphysical, cosmological, and ethical principles of the traditions in which they developed, the new science knew no bounds and claimed for itself totality, 
reducing all of reality to mechanistic and mathematical models with raw empirical data limited to the terrestrial plane. Although Professor Nasr does not deny the validity of the findings of this science, he argues that this knowledge of the "quantitative face" of nature came at the expense of its "spiritual face" in which all things turn to worship God:

Henceforth as long as only the quantitative face of nature was considered as real, and the new science was seen as the only science of nature, the religious meaning of the order of nature was irrelevant, at best an emotional and poetic response to "matter in motion." (p. 143)

Discussing current developments in science, Professor Nasr reveals the cracks forming in its edifice and the openings leading to the religious understanding of nature. He stresses that the only way to establish a sacred science (or to "Islamize knowledge," using the terminology of this journal) is to first create "space" for it by removing errors which are obstacles to it. He maintains that this can only come about by understanding the modern scientific worldview and the manner in which it has eclipsed the spiritual significance of nature. The chapter "Scientific Revolution" applies the sword of Truth to create this "space," and is essential reading for those who are interested in the "Islamization of knowledge."

The following chapter, "Tragic Consequences of Humanism in the West," seals this discussion on the rise of the scientistic worldview and its relationship to viewing man solely within his terrestrial context. Since man without God is not fully man, secular humanism can only give rise to the infra-human. In fact, he opens this chapter with a forceful reminder of what accompanied this new "humanism," writing that it is not easy to understand

how fewer than two hundred men from western Spain could defeat the entire Incan Empire in Peru and bring about the death of 4 million of 8 million inhabitants of that land in a decade, while debating whether the people the invaders were slaughtering had souls and whether or not they were human. (p. 163)

Another key point made in this chapter relates to how the new conception of man inverted the relationship between being and doing. Whereas the traditional religious view always maintained that being determines action, humanists such as Pico asserted that "the being of man follows from his doing," that being was contingent on action. Professor Nasr comments:

$\mathrm{He}$ (Pico) thus stated philosophically the thesis of the primacy of action over contemplation and doing over being, which characterizes modern man and which has been of the greatest consequence for the destruction of the world of nature. The unlimited energy of a civilization turned totally outward to remold the natural world in complete "freedom". . is at the heart of the relentless activity of modern man in the destruction of the natural environment vis-a-vis which he cannot simply "be" but toward which he must act aggressively to change and transform it. (p. 174)

The next chapter, "The Rediscovery of Nature: Religion and the Environmental Crisis," provides an overview of the various responses from 
Christian, Jewish, Muslim, and other religious thinkers to the environmental crisis in the last several decades. It is followed by the chapter "Wisdom of the Body" which provides a profound analysis of the correspondence between the macrocosm of nature and the microcosm of the body. This may be an area of discovery for many readers, and Professor Nasr begins with the premise that the body is sacred according to all traditional religions. He argues that the profane treatment of nature by modern man also applies to the desacralization of the human body, which is trivialized in the reductionist approach of modern medicine. Therefore, attempts to oppose the tendencies responsible for the environmental crisis must include an appreciation of the inner environment that is the human body. Professor Nasr substantiates this for the different religious traditions, and closes the chapter with an inspiring conclusion:

To rediscover the body as the abode of the Spirit, worthy of Resurrection before the Lord, and intimate companion in the soul's journey in this world, sacred in itself and in the life which permeates it, is to rediscover at the same time the sacredness of nature. It is to reestablish our link with the plants and animals, with the streams, mountains and the stars. It is to experience the presence of the Spirit in the physical dimension of our existence as well as in the world of nature to which we are linked both physically and spiritually, through our bodies as well as our souls and the Spirit which is reflected in both our bodies as the temples of God and the world of nature as the theater of theophanies and mirror of Divine Creativity. (p. 262)

The final chapter, "Religion and the Resacralization of Nature," eloquently relates these spiritual and ethical principles to the current environmental crisis. The chapter makes one aware of the inadequacies of current "solutions" which are not rooted in the traditional worldview. Indeed, the very idea of a "new ideology" betrays the individualistic and anti-traditional attitude which generated the problem in the first place. Professor Nasr, on the other hand, seeks to resuscitate the approach centered on the Absolute and Heaven. This alone guarantees that man can live in harmony with earth. As pointed out earlier, the environmental crisis is the result of a spiritual crisis within man, and only by being centered on the Absolute can man be taught the virtues of restraint and moderation:

it is only traditional religions, with their roots sunk in the Divine and their means of directing the soul to its ultimate goal, that can provide a real cure for the illusion of a centerless soul seeking the Infinite in the multiplicity of nature and the Absolute in its circumferential mode of existence. Only religion can discipline the soul to live more ascetically, to accept the virtue of simple living and frugality as ornaments of the soul, and to see such sins as greed for exactly what they are. (p. 272)

Religions also provide the ritual power to affect the cosmos, an idea which is integral to all major traditions. Thus, Professor Nasr argues that religion must play a critical role in curing the imbalances and disharmonies in man's relationship to the environment on three levels: the plane of ethics of the individual, the plane of intellectual thought and the resacralization of nature, and the plane of 
the cosmos and the spiritual ambiance created by the performance of religious rites.

Professor Nasr is to be congratulated on this immense work which is a landmark in the resurgence of a sacred science on the religious order of nature. In presenting the religious view of the world, he makes clear the spiritual crisis that is the origin of the modern environmental crisis, and brings additional evidence to cast light on the unity of religions and spiritual thought. The book is both comprehensive and profound. Most importantly, it is spiritually rewarding, breaking the idols of the secular mind which are suffocating illusions, and clarifying the path of ascent to contemplating the order of nature which an ayah or symbol that leads to God.

Professor Nasr Arif Professor of Political Science and Economics School of Islamic and Social Sciences Leesburg, VA

1. Reza Shah-Kazemi, a review of Religion and the Order of Nature. Sophia: A Journal for Traditional Studies Winter (1996): 125.

2. Ibid, p. 127. 